\title{
Nadja Thoma \\ Identity Construction Strategies \\ in Muslim hip-hop. \\ A multimodal analysis of the work of the German rapper Sahira
}

Introduction

Identities, far from being fixed and stable categories determining people's minds, are defined as dynamic entities which form processes of bringing together and eventually stabilising different discourses and the social and cultural positions these discourses imply - specific ethnicities, races, genders, classes [Chouliaraki, 2003, Hall, 1996].

Recent studies about youth and youth cultures foster a cultural more than a social or physiological understanding of youth and emphasize the diversity of youth-cultural expressions worldwide [Androutsopoulos/ Georgakopoulou, 2003, p. 2-3]. In this regard, metropolitan youth culture is portrayed as borrowing symbolic means of expression from various languages and cultures [Auer/Dirim, 2003, p. 223].

The aim of this paper is to explore how young Muslim artists construct identity within contemporary hip-hop culture in Germany. Using the example of the rapper Sahira, I will focus on the following questions: Which strategies are used to express religious identities in hip-hop? Which modifications of the traditional hip-hop culture can be observed within and through elements of Muslim culture and religion?

The data used in the paper ranges from visual resources (a CD cover and the logo of the record label) to song lyrics and interview excerpts. Using such a multimodal analysis allows me to show how specific artistic, cultural and religious ideas appear in different contexts and how they stick together.

The paper unfolds in the following manner: The first section will offer an orientation towards hip-hop culture, introducing a number of important cultural concepts for the successive discussion. The second section will give an overview of discussions about the permissivity of music, especially hip-hop and Islam. The third section will deal with identity con- 
struction in German hip-hop culture. This section will be followed by a discussion of how cultural and religious identity is constructed in the work of the German rapper Sahira.

\section{An orientation towards hip-hop culture}

Hip-hop started in the 1970s in the ghettos of New York City as a youth culture movement that spread through the United States and beyond to become a favoured manner of artistic, sociocultural and political expression of a generation of globalized youth. Rooted in African-American language and culture, hip-hop has meanwhile acquired a variety of styles and verbal artistry that allows it to be used by artists of any origin, transcending linguistic, cultural and religious barriers.

Hip-hop culture is defined as having four major elements: MC'ing (rapping), DJ'ing, B-Boying/B-girling (several dance styles commonly referred to as breakdancing), and graffiti art (writing). To these, several scholars add the rap video as a fifth element as it developed its own style and its own genre conventions [Rose, 1994, p. 9]. Afrika Bambaataa, a founder of the hip-hop cultural movement, adds knowledge or "overstanding", a deeper and more critical conception than ,understanding" [Alim/Pennycook, 2007, p. 90]. All these elements have always been linked very close to each other and constitute the whole culture. Listening to music doesn't suffice to be accepted as a member of the culture. The active participation in at least one of the elements through a continuing and intensive competition for better and more innovative styles, frequently with intertextual references to already existing works, makes a real member of the community.

Hip-Hop is a highly competitive culture, and fame can be achieved through constantly performing and demonstrating one's abilities. In this regard, the battle as a basic constituent of hip-hop is of the utmost importance. It is a competition involving at least two members, and a victor is determined by the audience [Parmar/Bain, 2007, p. 141]. Rap battles are associated with lyrical techniques like boasting (a lyrical self-praise) and dissing (a verbal offence of the antagonist).

Rap is the element that has most been discussed both in public and in science. According to the rapper Chuck D, rap as "Black America's CNN"1 has the role to identify racist and discriminatory formations in society and to offer an alternative narrative to inform about the reality in the suburbs. Chuck D's definition of rap as a consciousness-raising resistance strategy was adapted by most scholars in Cultural Studies as an explanatory model for rap lyrics which are defined as a „driving force for change rather than only a representation of diversity“ [Alim/Pennycook, 2007, p. 98]. Beyond 
the reflection of sociocultural realities and the construction of identities, the hip-hop elements are urban practices with a high potential of transforming positions and creating new social connections and interactions which cast a different light on minority positions and put into question monocultural definitions of the urban area which is highly competitive for youth [Stemmler, 2007, p. 102-107].

With the transfer of hip-hop from the United States into other parts of the world, English lost its position as the exclusive and unique rap language, and sociocultural and political issues besides manifold questions of youth cultures from different countries, nations and cultures entered rap lyrics, videos and graffiti. Musical and dancing styles of different parts of the world were integrated into the existing artistic language. These hybrid art forms express the area of conflict between the Afro-American "Ghetto-Culture“ and local traditions. The combination of a global youth culture with different local elements makes hip-hop a glocal culture which makes it possible to create constantly new art forms between original and adaptation [Friedrich/ Klein, 2003, p. 9-10].

Rappers outside the United States adopted the structural elements of hip-hop culture and concentrated on issues that fit life in their respective countries. While American linguistic studies concentrated on Black Talk ${ }^{2}$ [Smitherman, 1973, 1977, Alim, 2001, 2005] and interpreted hip-hop as an Afro-American genre, studies concerning European rap lyrics have shown that European rappers basically use their mother tongue, and that bilingual second and third generation migrants use the dominant language of the society they live in [Androutsopoulos/Scholz, 2002:213]. Furthermore, dialects and minority languages are used [Nicolay/Waibel, 2006].

In addition to the manifold qualities of a rapper, his or her ethnic background has always been a benchmark for authenticity and credibility in the scene, and the topos of the „black man" as a member of a marginalized community and therefore predestined rapper was present in the community itself, in media and even in science. In the global context outside the United States, this role was assumed by members of other ethnic minorities which were confronted with similar experiences of social exclusion. Thus, hip-hop is strongly represented by the North-African community in France [Stemmler, 2007], the Asian community in Britain [Midolo, 2009] and the Turkish community in Germany [Androutsopoulos, 2003].

All these communities have a high number of Muslim members. Nonetheless, the issue of Islam in hip-hop has not yet been sufficiently explored.

2 | The speech of African Americans has also been defined by other terms, like black English, Ebonics, African American vernacular, and African American language. For the history of black language, its unique features and its impact on «standard English» see Smitherman 2000.

3 | The survey includes France, Germany, Italy, Spain and Greece. 


\section{Hip-Hop and Islam}

Religious permissibility of music as a point of law dates back to the beginnings of Islam, and the question if whether it was legal to listen to music and play instruments has been a point at issue until now. The Qur'an doesn't provide a definite argument for prohibition. Several interpretations by Islamic scholars to flesh out prohibition were refused by others, and thus the Sunna was consulted as an additional source of law [Fatoum, 1994, p. 29-35]. But while some ahādīt favour listening to music and the use of music instruments, others forbid it. Analogous to the unclear status of music in the holy writings, the legal doctrines have taken up different positions [Fatoum, 1994, p. 35-37] which are quoted and vividly discussed in musicrelated discussions among Muslims on the web.

Nevertheless, music has had an influental position throughout the history of Islam and has been diffused in almost every social stratum regardless of the severe criticism from some authorities. The relationship to music depends on the types of instruments used, the musicians, the context, the target strived for and the type of music [Fatoum, p. 74-77].

For many people, including Muslims, the term hip-hop is often associated with gangsta rap, a distinctive style of rapping that emerged in Los Angeles and deals with criminality, drugs and sex and which sometimes has misogynistic and homophobic contents. Therefore, the idea of any link between hip-hop and Islam has generated some confusion if not complete rejection among Muslims.

During the last decade, some scholars have written about the the connections between Islam and hip-hop [Alim, 2006, Khabeer, 2007, McMurray, 2008, Swedenburg, 2001], showing that hip-hop performers are „of critical importance for young Muslims“, as they create new spaces „for multi-faceted Islamic identities and as weapons in the battles against racist violence and Islamophobic discrimination" [Swedenburg, 2001, p. 76].

Alim highlights the Islamic roots of hip-hop, outlining „Islam's dynamic presence and central role" in the hip-hop community [Alim, 2006, p. 22]. In the introduction to his book, he uses Islamic phrases as well as hip-hop language, showing that a coexistence and hybridisation of both cultures is not as unfathomable as it may seem:

Bismillah Al-Rahman al-Rahim. In the Name of Allah, the Beneficent, the Merciful... Yo, first and foremost, as always, All Props and Praises due to the Most High. One Love.

[Alim, 2006, p.X.]

His invocation of the Basmala follows an Islamic tradition that encourages Muslims to recite this phrase in order to purify their intentions and actions, and this is also used by Islamic rappers [Khabeer, 207, p. 125]. Its translation into English makes the words intelligible for non-Muslims as 
well as people who don't understand Arabic. The interjection „yo“, which has multiple meanings and is typical in rap language, plus the words „Props and Praises" connect the Basmala with hip-hop language.

Khabeer gives an overview of American Muslim rappers and their impact on American hip-hop. He asserts that American Islamic hip hop artists see their work as serving two particular ends: to preserve the Islamic identity of Muslim youth and to educate non-Muslims about Islam and Muslims [Khabeer, 2007, p. 125]. Midolo accentuates the importance of hiphop as a diasporic music for Muslim immigrants from Asia in Britain [Midolo, 2009], and McMurray [2008] focuses on the role of black women in Islamic hip-hop music.

\section{Hip-hop and identity in Germany}

During the last decades, local and national rap styles have emerged and developed a degree of cultural autonomy alongside their connection to the original American cultural models ${ }^{4}$.

In Germany, hip-hop became one of the most important youth cultures and has been characterised by great heterogeneity from the beginning. In the early stages, German rappers performed in English, and rapping in German was said to be impossible and/or improper 5 . Among the first groups that rapped in German, two emerged as originators of two main styles; one fraction surrounded the group Die Fantastischen Vier, and focused on fun and partying, while the other style - tracing back to the multicultural group Advanced Chemistry - regarded the political aspect as the driving force of hip-hop culture and the main criterion for its further development [Berns/Schlobinski, 2003, p. 201]. The latter dealt critically with the living conditions of members of marginalised minority communities and functioned as an archetype of German conscious rap.

One of the main concepts of hip-hop is realness: For rappers it is not sufficient to simply import an attitude or to copy and reproduce styles and to base their identity as rappers on an imported concept. The topics and the language of songs have to correspond to the surrounding social conditions, which means, that they have to be real or authentic [Berns/ Schlobinski, 2003, p. 215]. German conscious rap has always been regarded as more real than the fun, even if a clear distinction between the styles is not always possible.

Hip-hop identities are often described as being located in a hybrid or "third" space [Bhabha, 2004] generated through the use of multiple languages and in reference to multiple cultural communities and ethnicities. Identities of individuals within a group are hybrid in so far as they

4 | For rap in different parts of the world see Mitchell (2001), in Senegal: Heinrich (2007), in France: Stemmler (2007), in Slovenia: Stancović (2007).

5 | Meanwhile there are multicultural groups with multilingual songs, like the group Deadline from Cologne. 
don't consist of fixed and immutable majorities and minorities but develop in a consistent dialogue that is characterised by tension between assimilation and maintenance of a distinctive ethnic minority [Androutsopoulos, 2006, p. 190].

For hip-hop artists, this positioning in a third space „[...] was also a call to social consciousness and a challenge to the "received wisdom" of the "histories" and sociopolitical structures in which the artists were embedded" [Sarkar/Allen, 2007, p. 125].

The largest number of Germany's minority residents are Turkish, with 2,5 million members. This number is closely connected with the Gastarbeiter program (guest-workers) of the 1960's when people from different parts of Turkey and Italy were recruited to bolster the economy. The Gastarbeiter were first given fixed-term employment contracts, and subsequently many of them settled down in Germany. The migration history of the Gastarbeiter has been frequently brought up as a central issue in rap lyrics 6 , and this shows that self-identification of second and third generation migrants is closely connected to the history of migration. This becomes appearant also in the speech style which uses elements from first languages, German and hybrid forms like the Kanak Sprak ${ }^{7}$.

In the following statement, the developement of a hybrid identity is expressed by the rapper Killa Hakan :

Ich bin hier geboren in Deutschland, weißt du? Natürlich hab'n wir, äh, sozusagen auch unsere deutsche Ader natürlich, weil wir... ich bin jetzt über dreißig und ich bin hier geboren, und ich hab natürlich die Kultur auch genommen, die deutsche. Wir fühlen uns nicht undeutsch, aber auch nicht richtig deutsch, auch nicht richtig türkisch so... Wir sind diese, diese eigene Kultur, die sich selbst erschaffen hat in Neukölln [Spiegel TV Magazin] ${ }^{8}$.

I was born here in Germany, you know? Of course we have, er, sort of something German in us, of course, because we... I am over 30 now and I was born here, and of course I've also adopted the culture, the German one. We don't feel un-German, but neither really German, and neither quite Turkish... We are this, this own culture, which created itself in Neukölln?

The hybrid identity or third space is in this case expressed by the challenge to define an unequivocal identity. The constrictive terms „don't feel“, „neither really“, "neither quite" accentuate the differences between his own

6 | English: The Sons of the Gastarbeita.

7 | Kanak is a pejorative and racist term used from Germans for immigrants and former Gastarbeiter, mainly with Turkish and Arabic background. The term experienced a semantic reinterpretation during the last years and is often used from immigrants as a positive sign for the affiliation to a hybrid culture. Feridun Zaimoğlu (1995) assimilated this idea with literary means and coined the term "Kanak Sprak" (kanak language).

8 | www.youtube.com/watch?v=nmIDEf8r_WQ\&feature=related (Retrieved June 06, 2010)

9 | Neukölln is a very populated inner-city locality of Berlin which is characterized by a high percentage of immigrants, especially of Turkish and Arab descent. 
hybrid identity and the conception of a „German“ or „Turkish“ identity which is easy to imagine and well definable.

Most of the members of the Turkish community have Muslim background, even if their attitudes towards religion may vary. Nevertheless, religion was not a topic discussed in German hip-hop for a long time. Religion as an issue in lyrics has mainly come up after September 11, 2001.

There are various Muslim rappers in the German-speaking world, and their use of Islamic references is highly heterogeneous both in terms of quality and quantity. The most famous among them is Ammar114 who started his carrier in 2000 and defines himself as an Islamic rapper ${ }^{10}$. Besides Ammar114, other rappers have released CDs with religious contents. Youtube, myspace and similar sites with user-generated content show a wide range of Islamic hip-hop songs, mostly from unknown artists.

Moreover, conversions about Islam from famous rappers both worldwide and in Germany have caused a sensation and support continued conversations about the permissibility of hip-hop within Islam, about the possible roles of Muslims in Europe and - in the case of the rapper Sahira about the role of (Muslim) women in hip-hop and in German society.

\section{Identity constructions of Muslim rappers in Germany - the case of Sahira}

Sahira is one of the most successful female rap artists in Germany. She was born in Palestine and grew up in a solid middle class district in Berlin. Her interest in religion started after the attacks on September 11, which led to a generalizing stigmatization of Islam and Muslims in Germany [Cizmelioglu, 2007]. Sahiras identity contains elements of different cultures and languges, which I will analyze on different levels.

\section{Visual representation of identity}

Roland Barthes (1972) argued that what he called texts include all forms of representation, not just words and images, but also rituals, clothes, films and other elements. Visual representations are closely linked to other discursive fields and senses other than the visual (words, sounds, practices, through which meaning is expressed) and have a particular place in constructing identities [Woodward, 2003, p. 28].

10 | Khabeer uses „the term Islamic rather than Muslim to distinguish a genre of hip hop music and culture created by American Muslims that seeks to comply with Islamic religious standards and practices and whose current and primary audience is Muslims. For example, Islamic hip hop may restrict the types of musical instruments used, generally does not employ expletives and frequently refers to issues of doctrinal import" [Khabeer, 2007, p. 126]. 


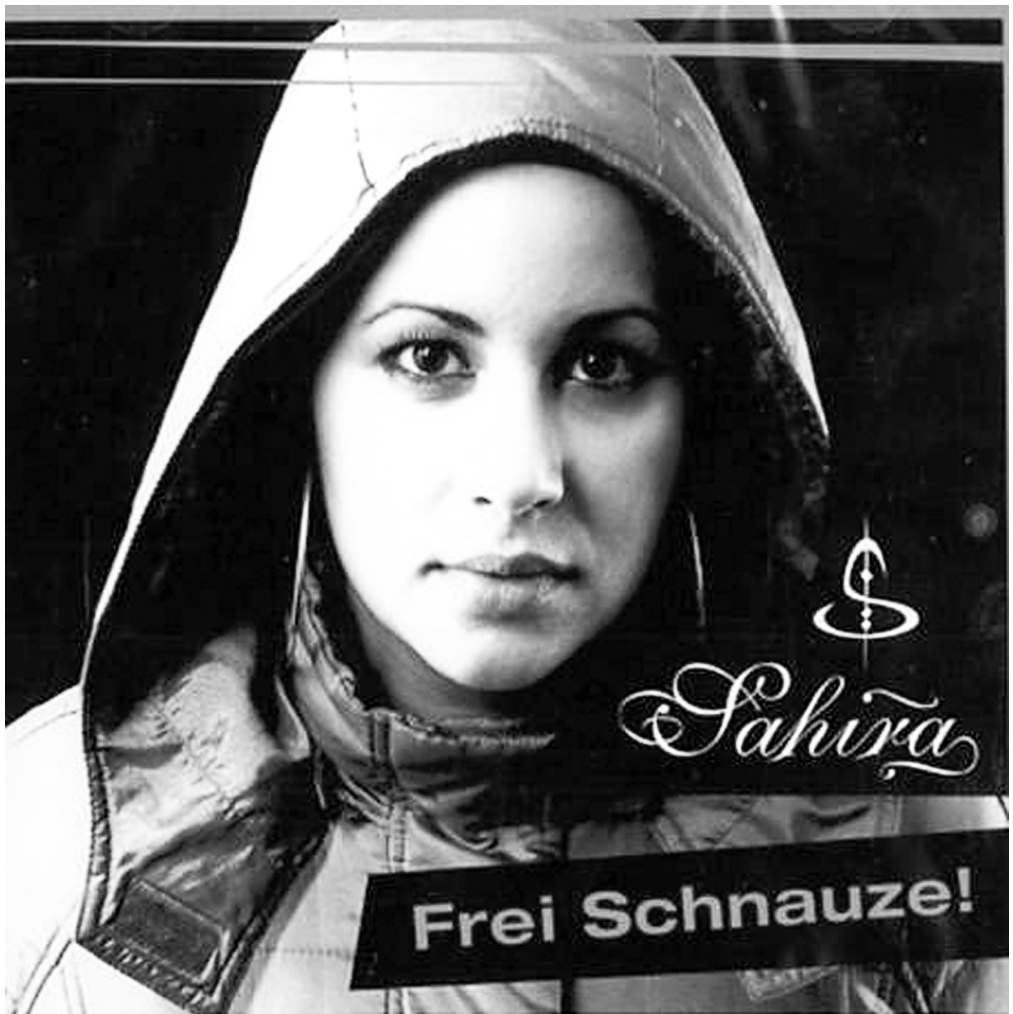

Sahira:

Frei Schnauze! Imanimusic $2005^{11}$

The cover of her CD "Frei Schnauze!" shows Sahira's head from the front view. She looks directly to the recipient and wears a jacket with a hood. Beyond functioning as an in-group marker, the hood is closely connected to graffiti writers who cover their heads while painting, and hence it functions as part of the visual communication within the hip-hop community. On the other hand it allows Sahira to cover her hair according to the Islamic custom.

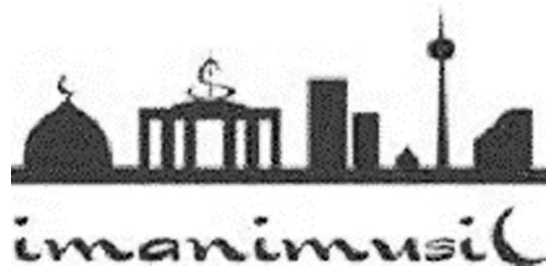


The logo of imanimusic, Sahira's own label, contains her religious affiliation in the name, and the last letter $\mathrm{c}$ has the form of a crescent as a symbol of Islam. The image above the label's name shows a skyline. At the left side there is a mosque with a crescent on its cupola, at the right side there is the Television Tower, Berlin's tallest structure, which is visible from many parts of the city. While the mosque symbolises Sahira's faith and her affiliation to Palestine, the Television Tower stands for Germany and perhaps also for the technical achievements of the West. Between the two buildings Sahira places the Brandenburg Gate, which stands as a symbol for the German Unity. On top of the Brandenburg Gate in Berlin is a sculpture of the winged goddess Minerva driving a quadriga into the city. On the CD cover Sahira replaces this sculpture with her own logo, thereby implicitly taking on the role of a goddess which can be read as a visual equivalent to the lyrical technique of boasting. Furthermore, she widens the symbolic power of the Brandenburg Gate by making it a symbol for the unity of the Muslim and the Western worlds, respectively Palestine and Germany. Moreover, by positioning her logo between these symbols, she shows her own (hybrid) position between and within both cultural and religious worlds.

Beside the title of the CD "Frei Schnauze!", the cover contains Sahira's name in Latin letters. When opening the $\mathrm{CD}$, her name appears in Arabic letters on the inside cover. What the recipient of the CD experiences when he or she opens it could be read as a symbol for (intercultural) encounters, which at first glance may show one side of a person and hide aspects which appear only upon closer examination.

\section{Linguistic representation of identity}

Sahira's first CD is entitled „Frei Schnauze!" 12 , a term that characterizes the glib style of speaking often associated with people from Berlin.

According to the narratology of Genette, a title of a book has the function to substitute the author as an intelligible object with the intention to convey something, and thus represents the work and raises certain expectations of the readers ${ }^{13}$.

With the title „Frei Schnauze!“, Sahira adapts a typical Berlin slang as a matter of course and defines herself as an integral part of Berlin's society. At the same time, she widens the definition of „Frei Schnauze“, traditionally associated with the German-speaking majority of Berlin by applying it to the artistic work of a member of a minority and showing thus the normality of mutual adoptions of linguistic and cultural attributes. A glib style of speaking is also one of the most important skills a rapper has to have when he or she wants to show realness and to win battles. 
In her songs, Sahira shows a professional handling of different rhyming forms, one of the key abilities of a good rapper.

Bin frei Schnauze ${ }^{14}$

Flistin ist auch mein Zuhause [...]

Was ich höre, dass ich störe

Mal wieder nicht zum Inventar gehöre

Ich schwöre Mann [...]

Ich trag mein Tuch, weil ich mag mein Tuch

Du jagst mein Tuch, weil du nicht mal versuchst $[\ldots]$

I'm freely speaking

Flistin is also my home $[. .$.

What I hear, that I'm bothering

And that once again I'm not part of the inventory

I swear, man [...]

I wear my shawl, because I like my shawl

You hunt my shawl, because you don't even try [...]

Mein Tipp: Lies nicht Bild, bild dich lieber! 15

My advice: Don't read the Bild, educate yourself!

In addition to the end rhymes (störe - gehöre) aligned with internal rhymes (höre - schwöre, trag - mag) she uses assonances (trag mein jagst mein, frei - mein), oblique rhymes (Schnauze - Zuhause), identic vowels (mein Túch - versúchst, nícht Bíld, bíld dích) and identical words (Tuch - Tuch), amplifying thus the linguistic variety ${ }^{16}$.

With the wordplay Lies nicht Bild, bild dich lieber, she refers to a German mass circulation tabloid whose reading should be replaced by study, a view that she often refers to in her lyrics and in interviews.

Apart from lyrical variation, different languages are used and connect to different communities and societies in Sahira's songs. Following the title of the CD "Frei Schnauze!", Sahira uses the dialect of Berlin when presenting opinions of people from Berlin in the song "Dit Tuch mit Aisha" (That shawl with Aisha):

Ick weiß nicht, warum die dit bloß mag, dit Tuch in ihrem Haar ${ }^{17}$

[...] Ick versteh dat nich so janz

I don't know, why on earth she likes it, that shawl in her hear

[...] I bearly understand that 
With the use of the dialect she shows her language proficiency not only in terms of active use and authentic pronounciation but also in terms of knowledge about the pragmatic use of it.

Beside the variety of Berlin dialect, Sahira uses English elements, which have already been shown to be an integral part of non-English rap discourse (Androutsopoulos/Scholz 2006):

Mein Kopf und mein Bauch haben den fight 1 ngst nicht gekl rt ${ }^{18}$ My head and my belly have in no way cleared the fight

Ey yo, ich bin frei Schnauze ${ }^{19}$

Ey yo, I speak freely

Nix is real an euch

You have nothing real about you

The subject of the fight is very common in hip-hop culture. The fight between her reason and her emotions are here compared with a battle-situation. The interjections "ey" and "yo" are among the most important ingroup-codes 20 of the hip-hop community. With the advice of the absent realness of other people, Sahira asserts her authority within the community.

In addition to rap language, Sahira uses Arabic terms, mostly in contexts which are related to Palestine:

Bin frei Schnauze, Flistin ist auch mein Zuhause 21

Am free speaking, Flistin is also my home

Beside the Arab words, she uses Islamic words to show not only her ethnic but also her religious background:

Imani, was immer auch kommen mag

Imani, whatever may come

Du bist so stolz, so rein, so weich, so warm, mashaallah ${ }^{22}$

Es ist mit dir so vollkommen zu sein, so warm, so klar, subhanallah

You are so proud, so immaculate, so soft, so warm, mashaallah

With you it is so perfect to be, so warm, so clear, subhanallah

Hey Schwester [...] Warum fragst du mich nicht nach'm Weg23

Hey sister [...] Why don't you ask me for the way?

18 | Sahira: Snippet. Online: www.myspace.com/sahiraimanimusic (Retrieved January 29, 2011).

19 | Sahira: Frei Schnauze. In Frei Schnauze! Imanimusic 2005.

20 | Keim 2004.

21 | Sahira: Frei Schnauze. In Frei Schnauze! Imanimusic 2005.

22 | Sahira: Snippet. Online: www.myspace.com/sahiraimanimusic (Retrieved January 29, 2011).

23 | Sahira: Dit Tuch mit Aisha. In Frei Schnauze! Imanimusic 2005. 
With Imani Sahira refers to Islam and includes an implicit reference to her label imanimusic. The Arabic words in the German song act as a symbol for the strength and confidence she gains from her religion and musical career. The words mashaallah and subhanallah are used by people with Muslim background to praise specific actions or to draw attention to the wonders of creation. In the song Dit Tuch mit Aisha, Sahira addresses a ficticious woman who is not on the right path in her opinion by repeatedly calling her Schwester (sister).

It has been stressed in the recent literature that through rap lyrics minority languages gain 'visibility' and higher status relative to the traditional order [Low/Sarkar/Winer, 2009, p. 77]. Furthermore, rap has been interpreted as a strategy for integration whereby young artists work to make their culture more visible in the public sphere and within the framework of media institutions of the larger society [Leblanc/Boudrealt-Fournier/ Djerrahian, 200724]. The results of these analyses are applicable for the music of the rapper Sahira, who allows Islam plenty of space in her work by using an Islamic language. This way, she succeeds in giving higher visibility to Islam and Muslims in Germany and amplifying the linguistic repertoire of rap lyrics, which traditionally have no religious vocabulary.

\section{c. Content-related representation of identity}

All the published newspaper articles about Sahira highlight the fact that she (voluntarily) wears the hijab, which is in Germany one of the most discussed topics regarding the integration of Muslims.

Hut ab, aber nicht Tuch ab [...] (Frei Schnauze)

Du jagst mein Tuch, weil du nicht mal versuchst

Einzusehn: Palästinenserin ist unterwegs in [...] Berlin

Hats off, but not shawl off [...]

You are hunting my shawl, because you don't even try

To understand: Palestinian woman is there in [...] Berlin

With the phrase hats off, which means to demonstrate respect to somebody, Sahira emphasizes the need of mutual respect in multicultural situations. At the same time, with but not shawl off, she clarifies her assumption about claims for a ban of the headscarf, which are in her opinion a limitation of religious liberty.

In terms of her ethnic affiliation Sahira shows her belonging to both Palestinian and German culture and/or nation: 


\section{Schnauze) \\ Bin Frei Schnauze. Kein Zweifel: Berlin mein Zuhause ${ }^{25}$ (Frei}

I speak freely. No doubt: Berlin my home.

Denkt ihr echt, Mann, ich bin nur deutsch?

Do you really think, man, that I am only German?

Hey Deutscher, denk mal nach 26

Ich bin nicht nur, aber auch Palästinenserin

Hey German, think twice

I am not only but also Palestinian

Jetzt mal zu euch Arabern... [...]

Habt die zwei Wörter, die ihr gehört habt, immerzu und immer noch im Repertoire [...]

Ich bin nicht von euch - Alhamdullillah

And regarding you, Arabs... [...]

You have the two words which you have heart

incessantly and still in your repertoire [...]

I am not from you — Alhamdullillah.

Sahira describes Berlin without ambiguity as her home. However, she narrows the image one could get when thinking about a person from Berlin, saying that she is not only German. In the last song on her CD, she addresses a ficticous German man, inviting him to reflect about her identity which is not only Palestinian, as it may seem when looking only at her outward appearance. In Frei Schnauze, she addresses a group of ficticious Arabs, accusing them of their insufficient German skills and ascertaining that she does not feel like a part of them.

In an interview with the Islamische Zeitung Sahira says:

"Our generation will find it difficult to say I am only German or I am only Arab or Turkish. When you say, I am Muslim, then it has no longer any relevance from were one comes"27.

In summary, Sahira accentuates her belonging to more than one culture, namely to the German and the Arab/Palestinian one which she defines as enrichment. Integration is in her point of view closely connected to a good command of German, which becomes clear when she criticizes Arabs who don't learn the language of their receiving country and to whom she doesn't want to belong.

The hybrid identity between two ethnicities and cultures can in her opinion be held together by the Muslim belief, which is a new concept in rap-lyrics.

25 | Sahira: Frei Schnauze. In Frei Schnauze! Imanimusic 2005.

26 | Sahira: Track 16. In Frei Schnauze! Imanimusic 2005.

27 | Aufgewachsen im “gut bürgerlichen" Berlin (2007). In: Islamische Zeitung (IZ), 09.05.2007. Online www. islamische-zeitung.de/?id=8768 (Retrieved January 29, 2011). 


\section{Conclusion}

Within the great diversity of German contemporary hip-hop culture, Muslim hip-hop has emerged as an independent style with great variety. One of the most famous Muslim rappers is Sahira, born in Palestine and living in Berlin. Through a multimodal analysis including both visual and linguistic aspects and the contents of her lyrics, I showed different strategies of identity-construction, which comprehend not only the ethnic, but also the religious affiliation.

The title of Sahira's CD, its visual elements and Sahira's clothing are a reference to the roots of hip-hop culture and show her knowledge of and part in it. Including typical elements of the city of Berlin, she also shows her understanding of local communication.

In her lyrics, Sahira uses English, standard German and dialect phrases as well as Arabic words, depending on the situation she is describing, showing thus that code-switching, far from being a chaotic form of expression, is a rule governed form which functions as a powerful in-group marker, as has been repeatedly stressed in the recent literature. In addition to these linguistic varieties, Sahira uses Islamic words within German phrases to underline her religious identity. The use of Islamic words within her lyrics is part of a social style and a form of self-presentation which activates social meanings and give higher visibility to Islam and Muslims in Germany.

To sum up, this multimodal analysis shows that German Muslim rap is the achievement of a recontextualization process, wherein a global cultural model has been adapted to a specific audience in a different reception country.

Beyond the mere use of different languages as markers for ethnic belonging, Sahira uses religious visual codes and linguistic phrases in order to transgress ethnic differences and monocultural, monoreligious or Islamophobic conceptions which, in her opinion, could restrict communication. Furthermore, the different visual and linguistic elements are a demonstration of Sahira's ability to insert new elements into the existing hip-hop culture, one of the abilities which label someone a good and real rapper.

\section{References}

\section{Bibliography}

Alim, H. Samy (2006): Roc the Mic Right. The Language of Hip Hop. New York, London: Routledge.

Alim, H. Samy; Pennycook, Alastair [2007]: Introduction to the Special Issue [Glocal Linguistic Flows: HipHop Culture(s), Identities and the Politics of Language Education]. In: Journal of Language, Identity and Education, Vol. 6, issue 2, p. 89-100. 
Androutsopoulos, Jannis (ed.) (2003): HipHop. Globale Kultur Lokale Praktiken. Bielefeld: transcript.

Androutsopoulos, Jannis (2006): Mehrsprachigkeit im deutschen Internet. In: Schlobinski, Peter (ed.): Von *hdl* bis *cul8r*. Sprache und Kommunikation in den Neuen Medien. Mannheim: Dudenverlag (Thema Deutsch, Band 7), p. 172-196.

Androutsopoulos, Jannis; Georgakopoulou, Alexandra (2003): Discourse constructions of youth identities. Introduction. In: Androutsopoulos, Jannis (ed.): HipHop. Globale Kultur - Lokale Praktiken. Bielefeld: transcript, p. 1-28.

Androutsopoulos, Jannis; Scholz, Arno (2006): Recontextualization: Hip-hop culture and rap lyrics in Europe. In: Linke, Angelika (ed.): Attraktion und Abwehr. Die Amerikanisierung der Alltagskultur in Europa. Köln, Wien u.a.: Böhlau (Alltag \& Kultur, 11), p. 289-304.

Berns, Jan; Schlobinski, Peter (2003): Construction of identity in German hip-hop culture. In: Androutsopoulos, Jannis K.; Georgakopoulou, Alexandra (ed.): Discourse constructions of youth identities. Amsterdam: Benjamins (Pragmatics \& beyond, N.S., 110), p. 197-222.

Bhabha, Homi K. (2004): The location of culture. London, New York: Routledge (Routledge classics).

Chouliaraki, Lilie (2003): Media and youth identities in a post-traditional order. In: Androutsopoulos, Jannis K.; Georgakopoulou, Alexandra (ed.): Discourse constructions of youth identities. Amsterdam: Benjamins (Pragmatics \& beyond, N.S., 110), p. 303-328.

Dimitriadis, Greg $\left(2004^{2}\right)$ : Performing Identity/Performing Culture. Hip Hop as Text, Pedagogy, and Lived Practice. In: McCarthy, Cameron/ Valdivia, Angharad N. (ed). Intersections in Communications and Culture. Global Approaches and Transdisciplinary Perspectives. Vol. 1). New York/ Wien/Berlin et al.

Dirim, İnci; Auer, Peter (2003): Socio-cultural orientation, urban youth styles and the spontaneous acquisition of Turkish by non-Turkish adolescents in Germany. In: Androutsopoulos, Jannis K.; Georgakopoulou, Alexandra (ed.): Discourse constructions of youth identities. Amsterdam: Benjamins (Pragmatics \& beyond, N.S., 110), p. 223-246.

Fatoum, Aly Abd-el-Gaphar (1994): Der Einfluß des islamischen Rechtsgutachtens (Fatwa) auf die ägyptische Rechtspraxis. Am Beispiel des Musikhörens. Frankfurt am Main, Wien u.a.: Lang (Heidelberger orientalistische Studien, 26).

Genette, Gérard (2001). Paratexte. Das Buch vom Beiwerk des Buches. Frankfurt/Main: Campus.

Hall, Stuart (1996): Who needs Identity? In: Hall, Stuart; Du Gay, Paul (ed.): Questions of Cultural Identity. London: Sage, p. 1-17.

Heinrich, Hans-Jörg (2007): Rapper im Senegal: Die Botschaft der Straße. In: Bock, Karin/Stefan Meier /Gunter Süss (ed.): HipHop meets 
Academia. Globale Spuren eines lokalen Kulturph nomens. Bielefeld: transcript (Studien zur Popularmusik), p. 117-136.

Keim, Inken (2004): Kommunikative Praktiken in t rkischst mmigen Kinder- und Jugendgruppen in Mannheim. In: Deutsche Sprache, vol. 32, issue 3, p. 198-226.

Khabeer, Suad Abdul (2007): Rap that Islam. The Rhyme and Reason of American Islamic Hip Hop. In: The Muslim World, vol. 97, p. 125-141.

Klein, Gabriele; Friedrich, Malte (2003): Is this real? Die Kultur des HipHop. Frankfurt am Main: Suhrkamp.

Low, Bronwen; Sarkar, Mela; Winer, Lise (2009): 'Ch'us mon propre Bescherelle'. Challenges from the Hip-Hop nation to the Quebec nation. In: Journal of Sociolinguistics, Vol. 13, issue 1, p. 59-82.

McMurray, Anaya (2008): Hotep and Hip-Hop. Can Black Muslim Women Be Down with Hip-Hop. In: Meridians: feminism, race, transnationalism, Vol. 8, Number 1, p. 74-92.

Midolo, Elena Dominique (2009): Flow of sounds. Musica e diaspora. Il rap islamico in Gran Bretagna. 1. ed. italiana. Napoli: Liguori (Profili Metropolis, 36).

Mitchell, Tony (ed.) (2001): Global noise. Rap and hip-hop outside the USA. Middletown CT: Wesleyan Univ. Press.

Nicolay, Mirta; Waibel, Saskia (2006): Hützutags we real wosch sie.... Hip-Hop in der Schweiz. In: Dürscheid, Christa \& Spitzmüller, Jürgen (Hrsg.): Zwischentöne. Zur Sprache der Jugend in der Deutschschweiz. Zürich: NZZ-Verlag, 115-144.

Parmar, Priya; Bain, Brionn (2007): Spoken Word and Hip Hop. The Power of Urban Art and Culture. In: Kincheloe, Joe L.; hayes, kecia (ed.): Teaching city kids. Understanding and appreciating them. New York, Washington, DC/Baltimore, Bern, Frankfurt am Main, Berlin, Brussels, Vienna, Oxford: Lang (Counterpoints), p. 131-156.

Pennycook, Alastair (2007): Language, Localization, and the Real. Hip-Hop and the Global Spread of Authenticity. In: Journal of Language, Identity and Education, Vol. 6, Number 2, p. 101-115.

Rose, Tricia (1994): Black Noise. Rap Music and Black Culture in Contemporary America. Hanover, London: Wesleyan University Press.

Sarkar, Mela; Allen, Dawn (2007): Hybrid Identities in Quebec HipHop. Language, Territory, and Ethnicity in the Mix. In: Journal of Language, Identity and Education, vol. 6, issue 2, p. 117-130.

Smitherman, Geneva (2000): Black talk. Words and phrases from the hood to the amen corner. Rev. ed. Boston: Houghton Mifflin.

Stanković, Peter (2007): HipHop in Slovenien: Gibt es Muster lokaler Aneignung eines globalen Genres? In: Bock, Karin/Stefan Meier /Gunter Süss (ed.): HipHop meets Academia. Globale Spuren eines lokalen Kulturphänomens. Bielefeld: transcript (Studien zur Popularmusik), p. 89-103. 
Stemmler, Susanne (2007): Bienvenu dans la Zonarisk. Soundtrack des Aufstands in Frankreichs Vorstädten. In: Helms, Dietrich; Phleps, Thomas (ed): Sound and the City. Populäre Musik im urbanen Kontext. Bielefeld: transcript, p. 97-112.

Swedenburg, Ted (2001): Islamic Hip-Hop vs. Islamophobia. Aki Nawaz, Natacha Atlas, Akhenaton. In: Mitchell, Tony (Ed.): Global noise. Rap and hip-hop outside the USA. Middletown CT: Wesleyan Univ. Press, S. 57-85.

Zaimoğlu, Feridun (1995): Kanak Sprak. 24 Mißtöne vom Rande der Gesellschaft. Berlin: Rotbuch-Verl.

\section{Discography}

Sahira: Frei Schnauze! Imanimusic 2005

\section{Online Sources}

Aufgewachsen im "gut bürgerlichen" Berlin (2007). In: Islamische Zeitung (IZ), 09.05.2007: www.islamische-zeitung.de/?id=8768

CD Cover Sahira "Frei Schnauze!": www.hhv.de/ item_85479_1054649040.html

Cizmecioglu, Aygül: Sahira Awad rappt für Toleranz. Kopftuch ist Freiheit, 07.04.2007: www.n-tv.de/politik/dossier/Kopftuch-ist-Freiheitarticle221790.html

Interview with Killa Hakan: www.youtube.com/watch?v=nmIDEf8r WQ\&feature $=$ related

Website Sahira: www.myspace.com/sahiraimanimusic 